\title{
Narrador: mediador simbólico de leitura
}

\section{Narrator: symbolic mediator for reading}

\author{
Lovani Volmer ${ }^{1}$ \\ Flavia Brocchetto Ramos ${ }^{2}$ \\ Rosemari Lorenz Martins ${ }^{3}$
}

Recebido em: 17/12/2020

Aprovado em: 22/06/2021

Publicado em: 30/07/2021

Resumo: O presente estudo insere-se no campo da leitura, mais especificamente no de narrativas literárias infantis, e centraliza sua atenção na atuação do narrador. A partir da hipótese de que essa instância narrativa, cuja escolha constitui-se não apenas entre duas formas gramaticais, mas entre duas atitudes narrativas, pode ser considerada mediadora simbólica de leitura e com a intenção de contribuir para a prática docente, sobretudo a respeito da seleção de narrativas, pretendemos, a partir da análise de obra literária infantil, averiguar a possibilidade de o narrador ser um mediador simbólico de leitura. Após leitura e levantamento dos elementos que compõem a história, direcionamos nosso olhar para o seu discurso, especialmente à atuação do narrador. Com base no aporte teórico e nas análises, podemos considerar a mediação simbólica também uma função do narrador.

Palavras-chave: Leitura; Mediação; Narrativa literária; Função do narrador.

\begin{abstract}
The present study is focused in the area of reading, more specifically in children's literary narratives, and centers its attention in the narrator's action. It stems from the hypothesis that this narrative instance, whose choice is constituted not only between two grammatical forms but between two narrative attitudes, could be considered as a symbolic mediation for reading. Therefore, with the intent to contribute to the teaching practice, especially when it concerns the selection of narratives, this study aims at verifying the possibility of the narrator being a symbolic mediator for the reading process. After reading and gathering the elements which assemble the story, a closer look is directed to discourse, specifically to the narrator's action. Based on the theoretical literature review and the analyses, it is possible to consider that symbolic mediation is also a function of the narrator.
\end{abstract}

Keywords: Reading; Mediation; Literary narrative; Narrator's function.

1. Professora na Universidade Feevale. Doutora em Letras, ênfase em Leitura e Linguagens, pela UCS/Uniritter; mestre em Letras, ênfase em Leitura e Cognição, pela UNISC; especialista em Informática Educativa pela Universidade Feevale; e graduada em Letras - Português/Alemão pela Unisinos. ORCID: 0000-0002-3458-1005. E-mail: lovaniv@feevale.br.

2. Professora Adjunto I na Universidade de Caxias do Sul. Doutora e Mestre em Letras pela PUCRS; especialista em Literatura Brasileira pela PUCRS; e graduada em Letras e Biblioteconomia pela UCS. Atualmente atua como pesquisadora sênior na Universidade de Lisboa, no Instituto de Ciências Sociais, sob orientação de José Machado Pais. ORCID: 0000-0002-1488-0534. E-mail: ramosfb@hotmail.com.

3. Professora na Universidade Feevale. Doutora em Letras pela PUCRS; mestre em Ciências da Comunicação pela Unisinos; especialista em Linguística do Texto pela Unisinos; e graduada em LetrasPortuguês/Alemão pela Unisinos. ORCID: 0000-0003-0658-5508. E-mail: rosel@feevale.br. 


\section{INTRODUÇÃO}

$\mathrm{Na}$ infância, em especial, a leitura literária contribui para a abertura do campo do imaginário, permitindo ao leitor decifrar sua própria experiência. $O$ acesso à literatura não se dá, contudo, apenas pelo contato físico da criança com o livro. Para que uma obra seja fruída na sua inteireza, é preciso que seja manuseada, degustada, é preciso abrir o livro, lê-lo, o que, dependendo da habilidade de leitura do leitor, requer, ora mais ora menos, mediação. Ao pensarmos a leitura, lembramo-nos de Magda Soares (2005), que alerta ao fato de a leitura ser uma ação transitiva; ler está acompanhado de um objeto - ler o quê? Nesse sentido, considerando o contexto brasileiro, em que, muitas vezes, o leitor iniciante não tem, durante sua leitura, a mediação de alguém, propomo-nos, neste estudo, a partir da leitura e análise de uma narrativa infantil, Betina, de Nilma Lino Gomes, a discutir a atuação do narrador como mediador simbólico de leitura e, assim, como o responsável por nos aproximar ou distanciar, nos mostrar ou esconder, nos envolver mais ou menos no mundo narrado.

Embora estudos sobre narrativas infantis no Brasil sejam inúmeros, especificamente acerca do papel do narrador como mediador de leitura de narrativas infantis são ainda incipientes. Assim, em um primeiro momento, as lentes estarão voltadas para a narrativa literária, sua organização e seus elementos, com ênfase no narrador e no papel desempenhado por esse "ser de papel" na tarefa de orientar a leitura e, desse modo, auxiliar o leitor na compreensão do que está lendo, ou seja, na mediação. A seguir, considerando que a escolha do narrador se constitui não apenas entre duas formas gramaticais, mas entre duas atitudes narrativas, visando à sistematização da reflexão que vem sendo realizada, o olhar fixar-se-á em Betina, tanto no que diz respeito aos elementos que compõem a sua história quanto ao seu discurso.

\section{A "visão" e a "cegueira" na narrativa literária}

A habilidade de narrar, específica do ser humano e sua inteligência, é parte integrante da sua competência linguística e simbólica. De acordo com Barthes et al. (1971, p. 18),

[...] não há em parte alguma povo algum sem narrativa; todas as classes, todos os grupos humanos têm suas narrativas, e freqüentemente (sic) estas narrativas são apreciadas em comum por homens de cultura diferente, e mesmo oposta; a narrativa ridiculariza a boa e a má literatura; internacional, trans-histórica, transcultural; a narrativa está aí, como a vida.

Estamos imersos em estruturas narrativas, que contemplam formas linguísticas e discursivas com as quais construímos e expressamos nossa subjetividade. Desse jogo 
VOLMER, L.; RAMOS, F.B.; MARTINS, R.L.

linguístico, sempre participam também os ouvintes/leitores - a construção de uma narrativa precisa de sua cooperação, e, como não há narrativa sem narrador e sem ouvinte/leitor, a narrativa verbal é construída dialogicamente, em um discurso.

O ato de narrar é uma forma particular e completa de enunciação e, no caso de narrativas ficcionais, há sempre uma transposição dos acontecimentos do mundo real que inspiram o relatado, ou seja, o que é narrado é feito de tal forma que parece real. Para Iser (1996), o texto ficcional é um ato de fingir, pelo qual aparecem finalidades que não pertencem à realidade repetida, ou seja, o texto ficcional apresenta uma realidade de todo reconhecível, posta, entretanto, sob o signo do fingimento.

Pelo reconhecimento do fingir, todo o mundo organizado no texto literário transforma-se em um como se, isto é, o mundo representado não é propriamente mundo, mas que, por efeito de um determinado fim, deve ser representado como se fosse. Nesse sentido, como se pode ser denominado de imaginário, porque os atos de fingir relacionam-se com o imaginário. O mundo contemplado no texto não se refere a si mesmo e, por seu caráter remissivo, representa algo diverso de si próprio. O mundo concebido é, assim, apenas um mundo possível, diferenciando-se daqueles de cujo material foi feito em virtude da fabulação presente na ficção.

No que diz respeito à organização das narrativas, Adam (1987) considera que todo texto narrativo tradicional apresenta uma estrutura comum, embora as mais contemporâneas possam romper com essa organização:

1) estado inicial (El): é o início, o começo da história, caracterizado por apresentar os actantes, o lugar e as circunstâncias numa situação estável, equilibrada;

2) força transformadora (FT): introduz uma força que vai perturbar o equilíbrio do estado inicial, a qual gera o momento seguinte;

3) dinâmica da ação (DA): é caracterizada por apresentar situações narrativas que ora pendem para a melhoria, ora para a degradação;

4) força equilibrante (FE): introduz uma segunda força que vai devolver à narrativa a situação de equilíbrio, confirmando a melhoria ou degradação na narrativa;

5) estado final (EF): apresenta as consequências possíveis e pertinentes ao que foi estabelecido e mostrado anteriormente, sendo coerente com os quatro momentos que o antecedem e restaurando o equilíbrio perdido, sem ser, obrigatoriamente, igual ao estado inicial.

Além disso, independentemente da sua estrutura, uma mesma história pode ser contada de modos distintos, conforme o repertório de quem conta, as intenções do contador, quem será o possível interlocutor (leitor ou ouvinte), onde será veiculada, entre 
outros pontos. Interessa a este estudo quem conta. Assim como a poesia é feita de sons e silêncios, a narrativa ficcional é feita de "visão e cegueira" (ECO, 1994), ou seja, o narrador pode se mostrar como um aliado do leitor e explicitar fatos ou, ainda, sonegar informações, desafiando-o a também atuar no processo de significação do texto. Só a relação com o narrador pode levar o leitor a uma visão de mundo que transpira da obra, atingindo a ideologia, os aspectos axiológicos nela veiculados.

Benjamin (1992) considera que a experiência que anda de boca em boca é a fonte de onde os narradores vão beber. O estudioso destaca que entre os inúmeros narradores anônimos, cujas experiências foram registradas através da narração de histórias, existem dois grupos, que se interpenetram de múltiplas maneiras: o viajante, que vem de longe e, ao retornar das viagens, conta as suas experiências; e o camponês, que revela o lugar onde vive, conhece as suas histórias e tradições. Assim, o narrador é quem sabe, quem viu, quem viveu, ou seja, um velho sábio que merece ser ouvido, porque sabe dar conselhos aos ouvintes.

O sentido construído pelos leitores depende, então, daquilo que é responsabilidade do narrador, o que, conforme Silva (1999), torna-o uma autoridade: a voz do narrador tem a função de representação, isto é, de produzir intratextualmente o universo diegético, e uma função de organização e controle das estruturas do texto narrativo, tanto no nível de tópico (microestruturas) como no transtópico (macroestruturas). Ou seja, a voz do narrador pode desempenhar uma função de interpretação do mundo narrado e assumir uma função de ação nesse mesmo mundo.

Quando lemos, contamos ou ouvimos uma história, estamos, pois, na companhia do narrador, que, ao narrar, deixa suas marcas. De acordo com Iser (1999), os comentários do narrador abrem certo jogo livre para a avaliação e permitem que novas lacunas apareçam no texto:

Assim, o narrador regula a distância entre o leitor e os eventos e, ao fazêlo, produz o efeito estético da história. Ao leitor é dada apenas informação suficiente para mantê-lo orientado e interessado, mas o narrador, deliberadamente, deixa abertas as inferências que deverão ser extraídas dessa informação. Em conseqüência (sic), espaços vazios são levados a ocorrer, estimulando a imaginação do leitor a averiguar a assunção que poderia ter motivado a atitude do narrador. Dessa forma, nos envolvemos porque reagimos aos pontos de vista antecipados pelo narrador. (ISER, 1999, p. 26).

A leitura depende, nesse sentido, daquilo que é responsabilidade do narrador, cujas inserções podem provocar uma variedade de respostas, uma vez que possibilitam pontos de vista múltiplos. Assim, ao lermos uma narrativa, mesmo sem perceber, levamos 
em conta as intenções do narrador, que conduz, em maior ou menor grau, a nossa significação, afinal,

[...] é ele que nos faz ver a ação pelos olhos de tal ou tal personagem, ou mesmo por seus próprios olhos, sem que lhe seja por isto necessário aparecer em cena. E ele, enfim, que escolhe relatar-nos tal peripécia através do diálogo de dois personagens ou mesmo por uma descrição 'objetiva'. (TODOROV, 1971, p. 245).

As funções do narrador não se esgotam, contudo, no ato de enunciação que lhe é atribuído. Ele é, como protagonista da narração, detentor de uma voz observável ao nível do enunciado por meio de intrusões, vestígios mais ou menos discretos da sua subjetividade, que articulam uma ideologia ou simples apreciação particular sobre os eventos relatados e as personagens referidas. A narrativa pode fornecer, por exemplo, de acordo com a perspectiva adotada e o grau de presença do narrador, mais ou menos detalhes ao leitor, de forma mais ou menos direta, e, assim, mantê-lo mais ou menos distante dos fatos narrados.

Genette (s/d), ao fazer referência ao sujeito fictício da enunciação, destaca a presença de dois tipos de narrador:

a) narrador homodiegético: veicula informações advindas de sua própria experiência diegética; tendo vivido a história como personagem, retirou daí as informações de que carece para construir seu relato. Participou da história, mas não como protagonista - caso o narrador seja o protagonista, ele será um narrador autodiegético;

b) narrador heterodiegético: relata uma história à qual é estranho, uma vez que não integra nem integrou, como personagem, o universo diegético em questão.

O narrador autodiegético, ao narrar suas próprias vivências como protagonista, tem o leitor mais próximo de si, podendo este, inclusive, confundir-se com aquele na vivência das ações, que, narradas em $1^{\text {a }}$ pessoa, facilitam a adesão ao narrado - narrador e narratário podem facilmente confundir-se. O mesmo pode acontecer com o narrador homodiegético, porém, em menor grau, uma vez que a tendência é haver identificação com o protagonista. Quando o narrador relata a história de outrem, ou seja, é heterodiegético, faz-se necessário um engajamento narrativo maior por parte do narrador, que precisará, pela coerência narrativa, dar "veracidade" ao narrado, pois não "viveu" a história.

Genette (s/d) também estabeleceu distinção entre o narrador e a perspectiva por ele adotada: a) perspectiva zero: o narrador não adota nenhum ponto de vista concreto e dá ao leitor uma informação completa, potencialmente ilimitada quanto ao âmbito de alcance. É onisciente, ou seja, sabe mais que qualquer personagem da trama; b) 
perspectiva externa: as personagens são vistas apenas externamente e o leitor não tem acesso aos seus pensamentos; c) perspectiva interna: o narrador restringe a informação ao ponto de vista de apenas uma personagem (perspectiva interna fixa) ou de várias (perspectiva interna variável).

Além disso, o ser de papel que conduz nossa leitura pode, ainda, de acordo com Genette (s/d), ter outro papel além da narração propriamente dita, ou seja, pode exercer outras funções na narrativa, que não existem isoladas, mas são determinadas, quais sejam:

a) função narrativa: nenhum narrador pode se desviar desse papel, sem o qual a história não acontece;

b) função de regência: diz respeito ao texto narrativo, ou seja, à forma como o narrador organiza internamente a narrativa;

c) função da comunicação: diz respeito à situação narrativa, cujos protagonistas são o narratário e o próprio narrador, uma vez que este estabelece, de forma direta ou indireta, contato ou diálogo com aquele;

d) função testemunhal: ocorre quando o narrador informa a fonte de suas informações, compartilha seus sentimentos frente a determinados episódios ou, ainda, o grau de precisão de suas memórias;

e) função ideológica: diz respeito às intervenções, diretas ou indiretas, que o narrador faz ao longo da narrativa, em que expõe opinião acerca de alguma ação ou personagem.

Nesse sentido, ao situar ou não as ações em um tempo e um espaço, podendo ocupar ou não diferentes posições, adotar ou não perspectivas diversas e, também, indicar ou não suas atitudes, o narrador modaliza seu relato. Os elementos linguísticos, responsáveis pela modalização, contudo, não constituem uma categoria homogênea, pois as narrativas orais, por exemplo, podem contar com o apoio da entonação, de gestos e expressões faciais. Na escrita, a tipografia permite a transcrição de muitos desses recursos, por meio, por exemplo, do uso de sinais de pontuação, interjeições, onomatopeias, entre outras possibilidades. Além disso, o próprio ritmo do discurso narrativo modaliza sutilmente o relato; a velocidade, a ordem ou a desordem dos fatos são fatores relacionados com a importância que o narrador confere aos diversos episódios narrados.

Ao transmitir o pensamento ou as falas das personagens, o narrador pode, por sua vez, se servir do discurso direto, do discurso indireto ou, ainda, segundo Othon Garcia (1985), de uma contaminação de ambos, o discurso indireto livre. Os verbos que no discurso direto indicam o interlocutor e no indireto constituem o núcleo do predicado da 
oração principal são chamados pelos gramáticos "verbos 'de elocução', dicendi ou declarandi, e, a muitos dos seus vicários, sentiendi." (GARCIA, 1985, p. 130). A principal função desses verbos é indicar o interlocutor que está com a palavra e pertencem a nove áreas semânticas, quais sejam:
a) de dizer (afirmar, declarar);
b) de perguntar (indagar, interrogar);
c) de responder (retrucar, replicar);
d) de contestar (negar, objetar);
e) de concordar (assentir, anuir);
f) de exclamar (gritar, bradar);
g) de pedir (solicitar, rogar);
h) de exortar (animar, aconselhar);
i) de ordenar (mandar, determinar). (GARCIA, 1985, p. 131).

A partir do Realismo, conforme o referido estudioso, passam a ser introduzidas nas narrativas uma enormidade de verbos de elocução que não são propriamente de "dizer", mas de "sentir": gemer, lamentar-se, suspirar, queixar-se, explodir, entre outros, que, por analogia, podem ser chamados sentiendi. Esses verbos têm, no geral, a função de caracterizar atitudes, gestos ou manifestações de conteúdo psíquico.

Garcia (1985) destaca que o narrador hábil saberá tirar proveito do uso desses verbos, que the oportunizam, pouco a pouco, ir retratando o caráter de suas personagens e/ou esclarecer quem é o interlocutor. Ao assumir o papel de enunciador, cabe ao narrador escolher os verbos de que fará uso, uma vez que a opção por este ou aquele implica sentidos peculiares. O estudioso chama a atenção, ainda, para a importância de não sobrecarregar as falas com essas adjunções, a fim de não cansar o leitor e prejudicar a espontaneidade dos diálogos.

No que diz respeito às predileções estilísticas das crianças nos primeiros anos do Ensino Fundamental, destacamos as apresentadas pelo estudioso alemão Bernhard Engelen (1995): preferência por frases curtas, voz ativa, por enunciados expressos na ordem direta em vez de frases com construções negativas, preferência por orações relativas a atributos complexos, assim como por orações principais ou com uma subordinada em vez de orações mais complexas.

\section{Narrar e mediar: ações do narrador}

Para ter acesso ao conhecimento acumulado ao longo da história humana e relacionar- -se com o mundo, os seres humanos participam de eventos que contam com mediação diversa. Mediar é uma interação baseada na produção de sentidos que surgem das relações que os homens estabelecem com o mundo e com outros sujeitos. A mediação tem como base teórica Vygostsky (1989), para quem a aprendizagem se dá na 
interação, que não ocorre ao natural; o sujeito precisa ser mediado/provocado para ser capaz de interagir e produzir sentido a partir daquilo que lê/ouve, por exemplo.

Vygotsky (1989) considera a mediação essencial para a aquisição das Funções Psicológicas Superiores - FPS, que se relacionam com ações intencionais, como planejamento, memória voluntária e imaginação: "[...] nas formas superiores do comportamento humano, o indivíduo modifica ativamente a situação estimuladora como uma parte do processo de resposta a ela." (VYGOTSKY, 1989, p. 15). Assim, o ser humano desenvolve-se e distingue-se dos demais animais através da mediação; sem ela, atividades psicológicas voluntárias, intencionais, controladas pelo próprio indivíduo seriam impossíveis.

Os estudos de Vygotsky (1989) permitem-nos pensar nos mediadores que atuam durante o processo de leitura - eles podem ser um instrumento físico, como livro, computador, professor, contador de histórias, ou simbólico, como, por exemplo, a linguagem, e têm a função de regular as ações que os indivíduos exercem sobre os objetos que possibilitam sua aprendizagem. O processo de mediação permite ao homem reelaborar sua realidade, recriando e significando os signos, a atividade e a consciência, levando-o a estabelecer relações sociointerativas.

Quanto à leitura e compreensão textual, Hauser (1977), baseado em Vygotsky, considera que toda pessoa ou instituição que se interpõe entre o texto e o leitor realiza uma ação de mediação, a qual pode ser útil ou inútil, ou seja, pode tanto promover como dificultar o contato do leitor com o texto. De acordo com o estudioso alemão,

[...] são muitos os casos que participam das mediações, graças às quais as obras se fazem pela primeira vez acessíveis, Ihes dão um sentido que o público possa compreender, e eliminam a estranheza inerente a sua novidade, suprem sua impressão desconcertante, as colocam de acordo com o habitual e familiar. (HAUSER, 1977, p. 592). ${ }^{1}$

Nesse sentido, consideramos que as estratégias discursivas exploradas pelos narradores nas tessituras das narrativas constituem-se estratégias simbólicas de mediação, pois promovem, pelas suas intervenções, o contato do leitor com o texto. Contudo, para ser mediador e efetivamente fazer a diferença no contato do leitor com a narrativa, esse narrador precisa ter algumas características específicas, quais sejam:

a) ser sábio: o narrador pode narrar sua experiência ou a de outros, mas deve ter profundo conhecimento sobre o narrado, o que se apresenta não apenas

\footnotetext{
1 Tradução livre da autora: "[...] son muchas las instancias que participan en las mediaciones, gracias a las cuales las obras se hacen por primera vez accesibles, les dan un sentido que el público puede comprender, y eliminan La extrañeza inherente en su novedad, suprimen su impresión desconcertante, las ponen de acuerdo con lo habitual y familiar." (HAUSER, 1977, p. 592).
}

Revista do SELL, Uberaba/MG (online) - V. 10 n. 1, p. 101-118, jan. /jun. - 2021. 
na história em si mas também nos detalhes daquilo que conta;

b) levar em consideração o universo de expectativa do leitor: o narrador deve contar a história de forma instigante, de tal forma que desperte a curiosidade do potencial leitor e permita-Ihe lê-la como se fosse real. Além disso, o vocabulário usado pelo narrador deve ser acessível e a estrutura frasal adequada ao público-alvo;

c) desafiar o leitor: o narrador deve chamar o leitor para o texto, o que pode acontecer de forma direta - quando o narrador interpela diretamente o leitor -, indireta - quando faz o uso da $1^{\text {a }}$ pessoa do singular (eu) ou do plural (nós), incluindo o leitor no texto - ou quando a situação-problema apresentada exige que ele se posicione, aceitando ou não o narrado, indignando-se, emocionando-se.

Trata-se, pois, com base nos princípios da mediação indicados por Vygotsky (1989), da ampliação das funções narrativas propostas por Genette (s/d) - além das funções narrativa, de regência, da comunicação, testemunhal e ideológica, o narrador teria, a nosso ver, a função de mediador simbólico de leitura. Assim sendo, a fim de averiguar como essa mediação se dá, vamos assentar nosso olhar em uma narrativa contemporânea infantil.

\section{Um olhar sobre Betina, de Nilma Lino Gomes}

A obra Betina, publicada inicialmente em 2009, é a primeira obra infantil de Nilma Lino Gomes, que tem suas escritas voltadas para as questões étnico-raciais, com ênfase especial na atuação do movimento negro brasileiro. Em 2013, lançou seu segundo livro infantil, $O$ menino coração de tambor.

Em Betina, como o próprio título sugere, a protagonista da história é Betina. Trata-se de uma menina afrodescendente, de origem simples, crescida com a presença marcante da avó, que fazia lindas tranças em seus cabelos e Ihe contava belas histórias. Apesar de não haver descrição do espaço, as ações das personagens e a relação entre elas permitem-nos inferir que a história se passa em contexto urbano, em típica cidade de interior, onde, no geral, as pessoas se conhecem e não há a correria desenfreada dos grandes centros urbanos:

No outro dia, ao sair à rua com os cabelos trançados, por onde a menina passava, os comentários eram: - Que tranças lindas! (GOMES, 2009, p. 12).

Ela [Betina] montou um salão de beleza que cuidava, trançava e penteava todos os tipos de cabelos e de todo tipo de gente. Mas o seu salão tinha algo especial: era um dos poucos na cidade que sabia pentear e trançar

Revista do SELL, Uberaba/MG (online) - V. 10 n. 1, p. 101-118, jan. /jun. - 2021. 
com muito charme e beleza os cabelos crespos. (GOMES, 2009, p. 20). ${ }^{2}$

Em relação ao desenvolvimento da história, percebemos, de forma bem clara, a estrutura narrativa proposta por Adam (1987), conforme segue:

1) estado inicial (EI): Betina, uma garota afrodescendentente, é frequentemente elogiada pelas pessoas por suas lindas tranças que a avó lhe faz;

2) força transformadora (FT): a avó vai envelhecendo e, pressentindo que logo se encontraria com seus ancestrais, faz uma proposta a Betina: ensinar-Ihe-ia a fazer tranças, desde que ajudasse cada pessoa que chegasse até ela "a se sentir bem, gostar mais de si, sentir-se feliz de ser como é, com o seu cabelo e a sua aparência." (p. 16). Betina aceita a proposta e aprende a trançar com a avó;

3) dinâmica da ação (DA): tempos depois, a avó vai se encontrar com seus ancestrais e Betina torna-se uma mulher adulta. Ela monta seu próprio salão e, conforme havia prometido à avó, "trançava e penteava todos os tipos de cabelos e de todo tipo de gente. [...] era um dos poucos na cidade que sabia pentear e trançar com muito charme e beleza os cabelos crespos." (p. 18);

4) força equilibrante (FE): Betina é convidada a palestrar em uma escola para falar sobre a arte de pentear e trançar;

5) estado final (EF): na escola, ao ouvir as perguntas dos alunos e respondê-las, chegam, juntos, à conclusão de que a arte de trançar "foi ensinada de mãe para filha, de tia para sobrinha, de avó para neta e assim por diante." (p. 22), uma forma muito comum de ensinar e aprender na história de muitas famílias, principalmente na das negras.

Betina cresceu com a presença marcante da avó, que lhe ensinou a fazer tranças, arte que passou de geração em geração na família. A garota tinha orgulho de ser negra, de ser como era, de usar o cabelo trançado e ter olhos pretos como jabuticabas. "Quando a avó terminava o penteado, Betina dava um pulo e corria para o espelho. Ela sempre gostava do que via. Do outro lado do espelho, sorria para ela uma menina negra, com dois olhos grandes e pretos como jabuticabas, [...]." (p. 8).

O espelho é, nesse sentido, um utensílio de suma importância na narrativa, pois referenda a autoafirmação da protagonista afrodescendente, uma criança feliz, em um país onde o preconceito racial ainda está presente em muitos espaços. A alegria da menina transcende a casa, vai para a rua, para a escola, onde invade o recreio: "No

\footnotetext{
${ }^{2}$ Nas próximas citações da obra Betina (2009), de Nilma Lino Gomes, será indicada apenas a página.
}

Revista do SELL, Uberaba/MG (online) - V. 10 n. 1, p. 101-118, jan. /jun. - 2021. 
recreio, várias coleguinhas perguntavam como as tranças eram feitas e Betina dava explicações toda cheia de pose." (p. 12).

O espaço escolar, onde, de certa forma, se manifestam os valores e anseios da sociedade, é urbano e desempenha importante função social nesta narrativa. Quando criança, é lá que consegue, com muita naturalidade, receber críticas em relação ao seu penteado: “- Para com isso! Tá com inveja, é?! Se quiser, peço a minha avó para fazer trancinha no seu cabelo também." (p. 12), demonstrando, como já mencionado, a autoconfiança de Betina. Depois de adulta, também em uma escola, conversa com crianças sobre a arte das tranças, que "foi ensinada de mãe para filha, de tia para sobrinha, de avó para neta e assim por diante. [...], uma forma muito comum de ensinar e aprender presente na história de muitas famílias brasileiras (e também de outros países), principalmente, as negras" (p. 22), revelando ao leitor traços da cultura africana.

A avó de Betina, pressentindo não ter mais muito tempo de vida, passou seus conhecimentos à neta, que aprendeu a trançar como ninguém e, quando adulta, abriu seu próprio salão de beleza, ficando muito famosa por suas tranças. O banquinho de outrora deu agora lugar a um espaço mais sofisticado, mas com o mesmo objetivo, ou seja, fazer as pessoas, especialmente as afrodescendentes, sentirem-se mais bonitas e felizes. Trata-se de obra que pretende trazer para a escola, para a infância brasileira contemporânea, a discussão acerca da valorização da cultura afro no Brasil e, assim, uma posição contra o preconceito racial.

\section{O narrador mediador}

A história da protagonista chega até o leitor pela voz de um narrador heterodiegético, ou seja, que não viveu como personagem aquilo que está contando ao leitor, mas com propriedade, retomando Benjamin (2007), revela as histórias e tradições da família de Betina, o que fica explícito já no início da narrativa:

O dia de fazer penteado novo era especial. A avó tirava as tranças ou o coque antigos, lavava o cabelo da neta, passava creme para desembaraçar, desembaraçava, lavava de novo e secava com a toalha. Nessa última etapa, o cabelo já não tinha mais creme. Uma dica: o segredo para um bom trançado é deixar o cabelo bem limpinho e sem creme. Evita caspa e facilita o manusear dos fios. (p. 6).

Mais do que nos "contar" a história, o narrador é um profundo conhecedor da cultura africana, sendo, inclusive, capaz de orientar o leitor, caso queira fazer tranças em seus cabelos, conforme explicitado no exemplo ora apresentado: "Uma dica". Nesse sentido, fazendo alusão aos estudos de Genette (s/d), temos um narrador onisciente e chamamos a atenção para sua função ideológica, a qual transparece também em outros 
momentos da narrativa, o que nos leva a inferir que tenha em seu horizonte um narratário que, de certa forma, desconhece a cultura afrodescendente.

Em Betina, quem tem a voz são os afrodescendentes, que têm a possibilidade de mostrar, por diferentes vozes, tanto do narrador como das personagens, um pouco da sua cultura, que, no geral, vem dos seus ancestrais, o que nos dá indícios do lugar dos mais velhos nessa cultura, ou seja, são valorizados:

- Quem são os ancestrais, vó? Ih! Acho que já sei. É gente morta, né?

- Mais ou menos, querida! São pessoas que nasceram bem antes de nós e já morreram. Algumas nasceram aqui mesmo, no Brasil, e outras viviam numa terra bem longe, chamada África. Elas nos deixaram ensinamentos e muita história de luta. A força e a coragem dessas pessoas continuam até hoje em nossas vidas e na história de cada um de nós. (p.14).

De acordo com o ser de papel que conduz nossa leitura, a avó de Betina era muito pacienciosa e "falava devagarzinho... devagarzinho... sua voz parecia música" ( $p$. 6). Aliás, a forma como o narrador organiza internamente a narrativa e a conduz transmite leveza ao texto, sugerindo ao leitor que sua leitura está sendo conduzida por um "contador de história". Essa sensação é transmitida pela descrição das ações das personagens, que são calmamente descritas, de tal forma que podemos visualizar as cenas: "a avó sentava-se em um banquinho, colocava uma almofada para Betina sentarse no chão, jogava uma toalha sobre os ombros da menina, dividia o cabelo em mechas e ia desembaraçando, [...]." (p.6). Cabe mencionarmos, ainda, que o narrador dita, inclusive, o ritmo de leitura do leitor e a sua entonação, ao explorar o uso dos sinais de pontuação, especialmente das reticências - explicitadas nos exemplos já citados - e das exclamações, conforme segue:

- Que tranças lindas! (p. 10).

- Lá vai Betina, de tranças novas! (p. 10).

- Parecem bordado! (p. 10).

- Mas aí vai colocar cabelo de mentira! Credo! - diziam outras colegas. (p. 12).

- Calma, gente! - alertava a garota. [...]. (p.12).

- Para com isso! Tá com inveja, é?! (p. 12).

[...] Trançava o cabelo da mãe, das irmãs, dos irmãos, dos primos, dos vizinhos e... acreditem!!! Até da avó! (p. 18).

Quem passava pelo salão da Betina saía de lá com os cabelos bem tratados, com penteados diferentes, tranças criativas e cheio de energia boa! Parecia mágica! (p. 18).

As exclamações são exploradas pelo narrador em diferentes situações, e ora expressam admiração, ora, surpresa, ora, alerta ou, ainda, indignação, fazendo com que o leitor sinta, junto com a personagem e/ou o narrador, essas diferentes sensações.

O narrador também se dirige, por vezes, diretamente ao seu narratário, trazendoo para o texto: "Trançava o cabelo da mãe, das irmãs, dos irmãos, dos primos, dos 
VOLMER, L.; RAMOS, F.B.; MARTINS, R.L.

vizinhos e... acreditem!!! Até da avó!" (p.18). Um pouco adiante, nessa mesma página: "O tempo passou ainda mais (êta tempo que voa, né?). [...] Mas, além de crescer, nossa Betina-menina-trançadeira virou Betina-mulher-cabeleireira"3. O narrador busca cumplicidade e convida o leitor a participar da história, convencendo-o de que realmente Betina é uma mulher negra, de fibra e feliz. Ao fazer uso do verbo "acreditar" no subjuntivo, o narrador está chamando a atenção de seu narratário, e consequentemente de seu leitor, no intuito de demonstrar quão bem Betina já estava trançando, sem se esquecer da relação de carinho que existia entre neta e avó. Com o uso do vício de linguagem "né", o narrador intensifica a oralidade e aproxima-se ainda mais do leitor; é como se estivesse em busca de cumplicidade. O pronome possessivo "nosso", por sua vez, envolve-o na leitura sem que este se dê conta; aquela garotinha "com cara de levada" (p. 6) agora é "nossa" Betina, ou seja, já faz parte das relações do leitor, é alguém próxima, assim como, indiretamente, sua cultura.

Mesmo sem expressar em palavras, o narrador dá informações suficientes que levam o leitor a perceber a relação de afeto que existia entre a avó e a neta - trata-se dos espaços vazios que cabem ao leitor preencher a que Iser (1999) faz menção em seus estudos. Seguem alguns trechos:

Enquanto trançava, avó e neta conversavam, cantavam e contavam histórias. Era tanta falação, tanta gargalhada que o tempo voava! (p. 6).

Avó e neta sorriram e se abraçaram. Naquele dia, as duas ficaram ainda mais amigas. (p. 16).

Betina pensava: "Se minha avó estivesse aqui, ela ia ficar orgulhosa! ", e os seus olhos derramavam lembranças. (p. 18).

No primeiro e segundo exemplos, embora não seja explicitada pelo narrador a relação de afeto que existia entre avó e neta, a descrição das cenas permite essa apreensão, o que faz com que o leitor, seguindo as pegadas do narrador, vá construindo o texto e suas relações. É possível, inclusive, visualizar as cenas, tal a habilidade do narrador ao contar como eram os momentos em que a avó trançava os cabelos da neta aliás, mais que momentos, eram rituais, pois seguiam alguns passos, ou seja, sempre a mesma sequência. Destacamos, ainda, que "o tempo voa" só quando estamos com pessoas de quem gostamos e quando a situação vivida é prazerosa. Além disso, o tempo conduzido pelo relógio inexistia nessa relação - em uma sociedade cada vez mais consumista e capitalista, em que tempo é sinônimo de dinheiro e as relações humanas, por vezes, resumem-se à virtualidade, temos aí também traços da cultura afro, que, de

${ }^{3}$ Grifo nosso.

Revista do SELL, Uberaba/MG (online) - V. 10 n. 1, p. 101-118, jan. /jun. - 2021. 
VOLMER, L.; RAMOS, F.B.; MARTINS, R.L.

acordo com o texto, preza valores simples, como estar junto, conversar, contar histórias e dar boas gargalhadas.

O exemplo da página 18 demonstra o quanto, mesmo depois de ter falecido, ou seja, ido para junto de seus ancestrais, conforme o narrador, a avó continua sendo presença marcante na vida de Betina, que tem muitas e boas lembranças da avó e do que aprendeu com ela. Esse exemplo é reafirmado pela protagonista no final da narrativa, quando explica que essa forma de ensinar e aprender - "de mãe para filha, de tia para sobrinha, de avó para neta e assim por diante." (p. 22) - é muito comum na história de muitas famílias brasileiras, inclusive na das afrodescendentes, reiterando as intenções para com seu possível narratário, conforme já explicitamos.

Em relação ao discurso, há predominância do discurso direto, e talvez seja esta mais uma forma de marcar a oralidade e ainda referendar/seduzir um leitor iniciante, uma vez que o texto se torna mais dinâmico. Para não cansar o leitor e prejudicar a espontaneidade dos diálogos, sempre que era possível identificar o interlocutor pelo contexto narrativo, o narrador optou por não o explicitar: isso ocorreu 14 vezes ao longo da narrativa. Como exemplo, citamos:

- O que é, vó! Bombom? É um conjuntinho de batom e esmalte?

- Não, sua tolinha! Vou lhe ensinar as fazer tranças.

- Mesmo? Oba! Oba! As meninas lá na escola vivem me pedindo para trançar os cabelos delas e eu ainda não sei... (p. 16).

Já os verbos utilizados pelo narrador para indicar a voz do outro - isso aconteceu 27 vezes, conforme pode ser visto no Quadro 1 - são, em sua maioria, da área semântica do dizer e do responder. Os verbos estão organizados, a seguir, conforme sua presença ao longo da narrativa.

Quadro 1 - Indicação dos verbos de dizer

\begin{tabular}{|l|c|c|c|c|c|c|}
\hline \multirow{2}{*}{$\begin{array}{c}\text { Verbos usados } \\
\text { pelo narrador }\end{array}$} & \multicolumn{5}{|c|}{ Área semântica } \\
\hline & dizer & exclamar & responder & Perguntar & concordar & exortar \\
\hline reclamar (p. 06) & & $\mathrm{B}^{4}$ & & & & \\
\hline ralhar (p. 06) & & & $\mathrm{A}^{5}$ & & & \\
\hline dizer (p. 06) & $\mathrm{B}$ & & & & & \\
\hline comentar (p. 10) & & $\mathrm{X}$ & & & & \\
\hline comentar (p. 10) & & $\mathrm{X}$ & & $\mathrm{X}$ & & \\
\hline responder (p. 10) & & & $\mathrm{B}$ & & & \\
\hline perguntar (p. 12) & & & & $\mathrm{X}$ & & \\
\hline dizer (p. 12) & $\mathrm{X}$ & & & & & \\
\hline alertar (p. 12) & $\mathrm{B}$ & & & & & \\
\hline responder (p. 12) & & & $\mathrm{B}$ & & & \\
\hline falar (p. 14) & & & & & & $\mathrm{A}$ \\
\hline
\end{tabular}


VOLMER, L.; RAMOS, F.B.; MARTINS, R.L.

\begin{tabular}{|c|c|c|c|c|c|c|}
\hline \multirow{2}{*}{$\begin{array}{l}\text { Verbos usados } \\
\text { pelo narrador }\end{array}$} & \multicolumn{6}{|c|}{ Área semântica } \\
\hline & dizer & exclamar & responder & Perguntar & concordar & exortar \\
\hline sorrir (p. 16) & & & & & & $A$ \\
\hline afirmar (p. 16) & A & & & & & \\
\hline arregalar (p. 16) & & & & A & & \\
\hline pensar (p. 18) & $B$ & & & & & \\
\hline responder (p. 20) & & & B & & & \\
\hline perguntar (p. 20) & & & & $\mathrm{X}$ & & \\
\hline responder (p. 20) & & & $B$ & & & \\
\hline dizer (p. 22) & B & & & & & \\
\hline dizer (p. 22) & $\mathrm{X}$ & & & & & \\
\hline responder (p. 22) & & & $B$ & & & \\
\hline perguntar (p. 22) & & & & $\mathrm{X}$ & & \\
\hline indagar (p. 22) & & & & $\mathrm{X}$ & & \\
\hline responder (p. 22) & & & $B$ & & & \\
\hline gritar (p. 22) & & & $\mathrm{X}$ & & & \\
\hline concluir (p. 22) & & $X$ & & & & \\
\hline explicar (p. 22) & $B$ & & & & & \\
\hline suspirar (p. 22) & & & & & $\mathrm{X}$ & \\
\hline
\end{tabular}

Fonte: elaborado pelas autoras.

A carga semântica dos verbos de dizer e de responder empregados revela-nos a personalidade forte de Betina, que sempre tinha uma declaração a fazer acerca de alguma coisa ou afirmar algo de positivo para alguém, e nunca deixava alguém sem resposta, o que se intensifica no final da narrativa, quando vai palestrar na escola. Salientamos, ainda, que os verbos do perguntar dizem respeito a indagações dirigidas à Betina, o que, igualmente, demonstra sua personalidade. Os verbos explorados pelo narrador nesta narrativa reiteram os estudos de Garcia (1985), segundo o qual o narrador habilidoso saberá tirar proveito do uso dos verbos dicendi, que lhe oportunizam, pouco a pouco, ir retratando suas personagens. Como exemplos, citamos:

Betina sorria com suas bochechas salientes e respondia, orgulhosa:

- Foi a minha vó quem fez. (p. 10). [quando alguém elogiava suas tranças]. Lá, no fundo, uma menina negra, com bochechas salientes e olhos pretos, levantou a mão e disse:

- Betina, quem ensinou você a trançar cabelo?

A cabeleireira respondeu:

- Foi a minha vó. - [...].

E quem ensinou a sua avó? - perguntou um menino negro de olhos cor de mel.

- A mãe dela. (p. 22).

As estruturas frasais observadas na construção do texto seguem, por sua vez, as indicações de Engelen (1995): as frases são curtas e prevalece a voz ativa, o que favorece a compreensão leitora das crianças nos anos iniciais do Ensino Fundamental e pode ser percebido nos exemplos já demonstrados.

O narrador em Betina também sabe mais que qualquer personagem da trama, ou seja, é onisciente e, portanto, sábio: "O dia de fazer penteado novo era especial." (p. 6). 
VOLMER, L.; RAMOS, F.B.; MARTINS, R.L.

Nesse caso, o narrador também interage com o narratário, é seu amigo, procura cumplicidade e, inclusive, dá-lhe dicas de como deve estar o cabelo para um bom trançado: "Uma dica: o segredo para um bom trançado é deixar o cabelo bem limpinho e sem creme. Evita caspa e facilita o manusear dos fios." (p. 6).

Além disso, o responsável por conduzir o leitor pelas veredas narrativas, conforme já explicitado, tem profundo conhecimento sobre o mundo narrado, ou seja, sobre a cultura africana. A sua perspectiva é zero, o que lhe permite tecer comentários sobre as personagens em diferentes situações e ter, inclusive, acesso aos seus pensamentos: "Betina pensava: 'Se minha vó estivesse aqui, ela ia ficar orgulhosa!', e os seus olhos derramavam lembranças." (p. 18). ${ }^{6}$ Esse comentário do narrador tem como alvo seu narratário, que, conforme já mencionamos, é um possível desconhecedor da cultura africana, ou seja, este narrador pretende envolvê-lo na história e convencê-lo do quanto Betina é uma garota, depois mulher, negra feliz, que está em paz com suas origens e assume, portanto, sua identidade.

\section{CONSIDERAÇÕES FINAIS}

Ao longo deste estudo, pretendemos averiguar a possibilidade de o narrador ser um mediador simbólico de leitura, especialmente porque, muitas vezes, no contexto das nossas famílias e escolas, o leitor não tem sua leitura mediada por alguém. Assim, em se tratando de narrativas infantis e, mais especificamente, de narrativas disponibilizadas para esse público ler sem a intermediação de um adulto, consideramos que as funções do narrador propostas por Genette (s/d) podem ser ampliadas: além das funções narrativa, de regência, da comunicação, testemunhal e ideológica, o narrador exerce também a função de mediador simbólico de leitura.

Nos momentos de leitura individual, a mediação precisa, pois, emergir da própria obra, a fim de regular as ações que os indivíduos exercem sobre os objetos que possibilitam sua aprendizagem. Nesse processo, a voz do narrador, responsável pelo jogo narrativo, desempenha papel fundamental, uma vez que tem tanto a função de produzir intratextualmente 0 universo diegético como de organizar e controlar das estruturas do texto. Sua atuação, portanto, é uma das responsáveis pela aproximação ou pelo distanciamento do leitor com a narrativa, pela validação do pacto que se instaura entre leitor e texto.

${ }^{6}$ Grifo nosso.

Revista do SELL, Uberaba/MG (online) - V. 10 n. 1, p. 101-118, jan. /jun. - 2021. 
VOLMER, L.; RAMOS, F.B.; MARTINS, R.L.

Em Betina, é esse narrador que faz com que simpatizemos com a protagonista e tenhamos afeição pela avó, que é a fonte de onde a narradora foi beber, parafraseando Benjamin (1992). Trata-se de uma narradora que, tal um camponês, pela interface com a avó, com profundo conhecimento sobre o narrado, revela-nos o lugar onde vive, as tradições e a história dos africanos e, referendando Iser (1999), arranca o leitor do assento confortável e exige atitude; a história que leu convida-o à ação.

Importante considerarmos que, de forma alguma, pretendemos excluir ou relegar a segundo plano a figura dos mediadores de leitura de "carne e osso", imprescindíveis no processo de democratização da leitura. Defendemos, porém, que, conforme a atuação do narrador na narrativa, esse processo de mediação pode se dar também nos momentos de leitura autônoma, individual.

Por fim, consideramos que este estudo traz, ainda, relevantes contribuições à ação docente, especialmente quando da seleção de textos para leitura dos alunos. Ao realizar a seleção de narrativas com narradores ora mais ora menos mediadores, o professor estará contribuindo para que o aluno se torne, gradativamente, um leitor autônomo.

\section{REFERÊNCIAS}

ADAM, Jean-michel. Types de séquences textuelles élémentaires. Pratiques, Metz, v. 56, p. 54-79, 1987.

BARTHES, Roland et al. Análise estrutural da narrativa: pesquisas semiológicas. Tradução de Maria Zilda Barbosa Pinto. Petrópolis: Vozes, 1971.

BENJAMIN, Walter. Erzählen: Schriften zur Theorie der Narration und zur literarischen Prosa. Frankfurt am Main: Suhrkamp, 2007.

BENJAMIN, Walter. Sobre arte, técnica, linguagem e política. Lisboa: Relógio D’Água, 1992.

ECO, Umberto. Seis passeios pelos bosques da ficção. Tradução de Hildegard Feist. São Paulo: Companhia das Letras, 1994.

ENGELEN, Bernhard. Überlegungen und Untersuchungen zur Syntax im Kinderbuch. In: FEINE, A.; SOMMERFELD, K. E. (Orgs.). Sprache und Stil in Texten für junge Leser. Festschrift für Hans - Joachim Siebert zum 65. Geburtstag. Frankfurt am Main: Lang, 1995, p. 43-63.

GARCIA, Othon Moacir. Comunicação em prosa moderna. Rio de Janeiro: Fundação Getúlio Vargas, 1985.

GENETTE, Gérard. Discurso da narrativa. Tradução de Maria Alzira Seixo. Lisboa: Editora Arcádia, s/d.

GOMES, Nelma Lino. Betina. II. Denise Nascimento. Belo Horizonte: Mazza, 2009.

Revista do SELL, Uberaba/MG (online) - V. 10 n. 1, p. 101-118, jan. /jun. - 2021. 
HAUSER, Arnold. Sociología del público. In: HAUSER, Arnold. Sociología del arte. Barcelona: Editorial Labor, 1977, p. 549-599.

ISER, Wolfgang. A indeterminação e a resposta do leitor na prosa de ficção. Tradução de Maria Angela Aguiar. Cadernos do Centro de Pesquisas Literárias da PUCRS - Série Traduções, Porto Alegre, v. 3, n. 2, mar. 1999.

ISER, Wolfgang. O fictício e o imaginário: perspectivas de uma antropologia literária. Tradução de Johannes Kretschmer. Rio de Janeiro: UERJ, 1996.

SOARES, Magda. Ler, verbo transitivo. In: PAIVA, A. et al. (Orgs.). Leituras literárias: discursos transitivos. Belo Horizonte: Autêntica, 2005.

TODOROV, Tzvetan. As categorias da narrativa literária. In: BARTHES, R. et al. Análise estrutural da narrativa: pesquisas semiológicas. Tradução de Maria Zilda Barbosa Pinto. Petrópolis: Vozes, 1971.

VYGOTSKY, Lev Semyonovich. A formação social da mente: o desenvolvimento dos processos psicológicos superiores. $3^{\text {a }}$ ed. São Paulo: Martins Fontes, 1989.

\footnotetext{
Como citar este artigo (ABNT)

VOLMER, L.; RAMOS, F.B.; MARTINS, R.L. Narrador: mediador simbólico de leitura. Revista do SELL, Uberaba, MG, v. 10, n. 01, p. 101-118, 2021. Disponível em: <inserir link de acesso >. Acesso em: inserir dia, mês e ano de acesso. DOI: inserir link do DOI. Como citar este artigo (APA)

Volmer, L., Ramos, F.B., \& Martins, R.L. (2021). Narrador: mediador simbólico de leitura. Revista do SELL, 10 (1), 101-118. DOI: inserir link completo de acesso ao DOI.
} 